\title{
A Report on Graduate Work in Qom on the Problems of Essence/Attribute and Substance/Accident
}

\author{
NARJES JAVANDEL SOUMEAHSARAEI, QOM
}

\section{Introduction}

The title of our workshop, "Substance and Attribute", will sound discordant to anyone coming from an Islamic philosophical background. In Islamic philosophy there are discussions of essence and attribute and of substance and accident, but no substance and attribute. Until fairly recently, it seems that the same was true of Western philosophy, certainly so in its medieval period. Discussions of substance stem from Aristotle's Categories, in which substance is contrasted with nine other categories which together are called accidents. The Greek term for accident, symbebekos, was rendered into Arabic as 'arad, indicating that which is passing. Discussions of essence and attribute entered into Islamic philosophy, however, not directly from the Greeks, but from early theological discussions among Muslim theologians, although as Muslim theology developed, Greek influence became increasingly prominent. The term translated as "attribute" is the Arabic sifat, which also means "adjective". The divine essence (dhat) or self, (nafs) was contrasted with the divine names and attributes (or nouns and adjectives). Indeed, Islamic theology or kalam is said to have begun with discussions about the attributes of God, particularly about divine speech.

One of the first questions disputed by the Muslim theologians was whether it was proper or not to use terms to describe God that are not mentioned in the Qur'an. In these discussions, the attributes of God are understood linguistically as the expressions used to describe divinity. From here, further questions were asked about the need to posit an eternal

\footnotetext{
* I would like to thank my husband, Hajj Dr. Muhammad Legenhausen, for his help with the preparation of this report.
} 
attribute to justify the application of the divine names mentioned in the Qur'an. If God is correctly described as the Living, some argued, it must be because of His possession of the attribute of life. Here we find a shift from the linguistic to an ontological understanding of the attributes within the early kalam tradition; but a sustained effort was made by $\mathrm{Mu}$ 'tazilite and Shi'ite theologians to deny that distinctions among the attributes imply any ontological distinctions within the divine essence, or that the attributes subsist alongside the divine essence as distinct realities. A further development of such disputes was that the terms "names" and "attributes" came to be used interchangeably.

One of the most influential of Shi'i theologians, Shaykh Mufid (d. 413/1022), says that an attribute is what informs a listener of an intended meaning and that as such, an attribute cannot exist without speech or writing to represent this meaning. ${ }^{1}$ The Ash'arites, on the other hand, invested the attributes with ontological rather than merely linguistic status, and thus have been described as defending a form of attribute realism. ${ }^{2}$ Needless to say, over the course of the centuries various Muslim thinkers have added considerable subtlety and nuance to their positions on the attributes; however, in contrast to philosophical discussions of the relationship between substance and accident, in which accidents were understood as "ways of being" since Aristotle, for the theologians, especially in the Shi' $i$ tradition, there has been much more reticence about admitting any real ontological status for the attributes.

The main attributes discussed in the tradition of Islamic kalam are: power, life, knowledge, hearing, sight, speech, and will. The attributes are divided into those of essence and those of act. The attributes of essence are those that necessarily and always are properly attributed to God, such as power, life, and knowledge. The attributes of act are those which it is appropriate to attribute to God only because of some divine action and are not appropriately attributed prior to the existence of the act, such as hearing, sight, speech, and will.

In addition to Islamic philosophy and kalam, we also find discussions related to the substance/accident and essence/attribute distinctions in what is called "theoretical mysticism" ("irfan nazari). Like the Shi'ite and $\mathrm{Mu}$ 'tazilites, the Sufis have also sought to guard the position of upholding the radical unity of God. Ibn 'Arabi (d. 1240) describes the relation between existence and entities in terms of the divine names. The names

\footnotetext{
${ }^{1}$ Shaykh Mufid 1371 A.H.; McDermott 1978, 134.

${ }^{2}$ McDermott 1978, 135.
} 
themselves are held to have no independent existence, but to be words that designate relations. ${ }^{3}$

Muslim philosophers, theologians and mystics have separated discussions of substance/accidents from discussions of (divine) essence/attributes to a large extent in order to place divinity beyond the categorial structure of ordinary concrete sensible objects described as substances in the Aristotelian tradition. Nevertheless, as we shall see below, there are important structural analogues between the discussions about the relationship between essence/attribute and substance/accident that can be found by reviewing the dissertations written on these topics.

\section{Essence/Attribute}

One of the areas that has attracted the attention of Muslim thinkers through the ages has been religious epistemology. The divine attributes have been studied from an epistemological point of view because it is through the attributes that God makes Himself known. This topic of the conditions under which attributions may correctly be made about God as reflections of human knowledge of Him has featured prominently in theological discussions of all the major sects of Islam.

In the Qur'an itself, there are numerous references to the divine names and attributes, and these have prompted some of the earliest theological discussions among Muslims. God shows man how He is to be known by introducing Himself through self-attribution. In many verses of the Qur'an, God describes Himself through particular attributes, and instructs believers to refer to Him by these attributes.

It is generally held that the essence of God is unknowable, and that because of this God can only be known through His attributes. The term for essence in the Qur'an and subsequently in Islamic theology is dhat. Literally, the word means mistress, in the sense of possessor (feminine). This should not be confused with essence in the sense of the Latin essentialesse distinction, for which the Arabic word mahiyyah is used. The dhat is the possessor of attributes, the self, identity, and in philosophical interpretations, being. After the Qur'an, the most important source for Islamic theology is hadiths, and in the sayings reported from the Prophet $(s)$ and Imams (' $a$ ) there is ample discussion of the divine essence and attributes. Ash'arite, Mu'tazilite and Shi'ite theologians all took positions on the nature of the divine attributes and their relation to the divine

\footnotetext{
${ }^{3}$ See Chittick 1998, 39.
} 
essence. In Shi'ite theology, this issue has featured in the works of all the prominent theologians, from Shaykh Saduq and Shaykh Mufid in the $4^{\text {th }} / 10^{\text {th }}$ century, through Majlisi and Lahiji of the Safavid period $\left(11^{\text {th }} / 17^{\text {th }}\right.$ century), and it continues to be discussed as a central part of contemporary Shi'ite theology, which over the course of time became interwoven with influences drawn from Islamic philosophy and mysticism.

In Shi 'ite thought, there has been a great emphasis on divine unity, and as a result, it is held that the divine attributes should not be considered as entities added to the divine essence. On the other hand, the attributes are held to be distinct from one another. God's knowledge is not His power, although each is one with the essence. Much of Shi'ite theology is devoted to discussions of how this paradox is to be resolved, generally by holding that the semantic diversity of the attributes is compatible with an ontological unity with essence.

The relation between the essence and attributes was viewed by the early Muslim philosophers in terms of Neo-Platonic emanation theory. The mystics also made use of such ideas, but emphasized the semantic relation between essence and attribute: differences in attribute are found in the different meanings through which divinity manifests Itself. The various strands of theological, philosophical and mystical speculation about the divine essence and attributes culminate with the work of Mulla Sadra, in the shadow of which all subsequent Islamic philosophy takes form.

Most of the dissertations about essence/attribute focus on how this topic is developed in one or more prominent Muslim thinkers or schools of thought. In some cases, there is a comparison with non-Muslim thinkers, such as Aristotle or Maimonides. Some attempt to understand the issue by going back to the sources in the Qur'an and hadiths, while others seek to defend the Shi 'ite position against other schools of thought. In virtually all the dissertations, an attempt is made to present the Shi 'ite theological position on this topic, particularly as elaborated in the school of Mulla Sadra, and to defend it against rivals or use it as a basis for the criticism of other positions.

Below is a list of twenty-one dissertations, arranged according to the type of approach taken to the issue of essence/attribute.

\subsection{Essence/Attribute in Islamic Sources}

2.11 The Divine Attributes from the Perspectives of the Qur'an and Mysticism 
2.12 Philosophical and Mystical Analysis of the Names and Attributes of God in the Psalms of Islam ${ }^{4}$

2.13 Imam Sadiq and the Divine Philosophy of the Essence and Attributes of God

2.14 Research in Prayers with regard to the Divine Essence and Attributes

2.2 Essence/Attribute in Islamic Theology

2.21 Unity of Attributes, and Deviations of the Ash'arites, Wahhabis and Other Groups

2.22 Divine Essence and Attributes in the View of Fakhr al-Din Razi

2.23 Review and Analysis of the Views of Ghazali about the Divine Essence and Attributes

2.24 Theological Views of Qadi Sa 'id Qummi

2.25 Semantics of the Divine Attributes

2.26 Semantics of Passive Attributes of God

2.27 A Comparison of the Views Allamah Hilli and Ardibilli about the Attributes of God and the Return

2.3 Essence/Attribute in Islamic Mysticism

2.31 Mutual Influences of the Ismailis and Sufis about Divine Unity

2.32 Immanence and Transcendence of God in the View of Ibn Arabi

2.4 Essence/Attribute in Islamic Philosophy and Comparative Philosophy

2.41 God in Aristotle and Ibn Sina

${ }^{4}$ See Zayn al-'Abidin 1987. 
2.42 Theology and the Quiddity of the Divine Attributes in the View of Maimonides and Allamah Tabataba'I

2.43 Negative Theology in the Views of Maimonides and Qadi Sa'id Qummi

2.44 Divine Essence and Attributes in the View of the Peripatetics and Illuminationists

\subsection{God in the View of Sohravardi}

2.46 Dialogue about the Divine Essence in Islamic Philosophy

2.47 A Review of the Attributes of God in the Views of Ibn Sina, Mulla Sadra, and Abd al-Jabbar Mu'tazili

2.48 A Review of the Criteria for Distinguishing the Attributes of Essence and Action in the Views of the Exegetes and Philosophers

Needless to say, the dissertations do not all keep neatly to these categories. There are comparisons between philosophers and theologians, philosophers and interpreters of the Qur'an, and general discussions, as well.

Discussions of Qadi Sa'id Qummi are often featured, since he represents a kind of negative theology that is generally perceived as extremist for its denial of the reality of the positive attributes. Students are encouraged to study how the position taken by Mulla Sadra is able to overcome the difficulties faced by Qadi Sa'id's negative theology.

There are structural similarities between the discussions of essence/attribute and substance/accident, although the discussions are completely separate. There are no discussions of substance/attribute or essence/accident in Islamic philosophy and theology. However, in Mulla Sadra, the identity of attributes with essence is mirrored in his claim that accidents have no existence other than the existence of the substance in which they inhere. Indeed, Mulla Sadra's views about substantial motion may be seen as a solution to the problem that arises when the Shi 'ite theological claim of the identity of attributes with the essence is used as a model for the relation between substance and accidents in changing entities. 


\section{Substance/Accident}

All of the dissertations about substance/accident focus on the doctrine of substantial motion, which is one of the most outstanding features of Mulla Sadra's thought. Some of the dissertations are purely descriptive, and attempt to present a clear exposition of Mulla Sadra's views on the issue. Others seek to defend Mulla Sadra's views from objections, or compare his views with others.

\subsection{General Explanations of Substantial Motion}

\subsection{Substantial Motion (1992)}

The M.A. thesis of Husayn Ali Qasimzadeh is divided into five chapters. The first gives the background to the substance notion in ancient Greek philosophy. The second chapter deals with the problems of defining motion and substance, as well as the place of substance among the categories and the types of substance. The third chapter reviews the philosophical and theological reasons for substantial motion. The fourth chapter considers the most famous objections to this doctrine and the answers given to them. Finally, the fifth chapter summarizes Mulla Sadra's position and elaborates the implications of substantial motion for the relation between rest and motion, the temporal origination of the world, time as a fourth material dimension, the corporeal resurrection, the relation between mind and body, and the rejection of reincarnation.

\subsection{Substance and Accident in the Views of Ibn Sina and Mulla Sadra (2000)}

Muhammad Mahdi Mishkati compares the views of the Islamic peripatetic school led by Ibn Sina with the views of the school of Transcendent Wisdom led by Mulla Sadra on the topic of substance/accident. While Ibn Sina is committed to the existence of both material and immaterial substances, Mulla Sadra, following Sohravardi, accepts the existence of a third, intermediate kind of substance: imaginal substances. Imaginal substances are like immaterial substances in that they do not have a place or spatial direction in the external world; but they are like corporeal substances in that they have a shape and size. Ibn Sina held that accidents themselves possess higher order accidents. Mulla Sadra rejected the arguments for this position without offering any arguments for the contrary position. Most famously, Ibn Sina and Mulla Sadra differ on whether there 
can be motion or change in accidents only, or in substance as well as accidents. Mulla Sadra argues that if Ibn Sina accepts that there is a persisting subject, primary matter, through generation and corruption, this can also serve as the subject of substantial motion, with the difference that in generation and corruption the change is discontinuous and sudden while in substantial motion the change is gradual. In addition to this argument, Mulla Sadra also maintains that the subject of motion is not a thing at rest that possesses motion, but that it is the moving existence of the subject itself, whose unity is preserved through continuity rather than through relation to a stationary subject or matter. The view of the relationship between substance and accident differs in Ibn Sina and Mulla Sadra in that Ibn Sina uses a causal model to explain the relationship. Substance is the agent cause of its accidents. In Mulla Sadra, however, the relation of substance to accident is much more intimate. Accidents are explained as relations of dependence to their substance that lack any existence of their own other than the existence of the substance.

\subsection{Review and Criticism of the Objection to Substantial Motion from the} Persistence of the Subject (1992)

Muhammad Baqiri Sabzavar devotes his M.A. thesis to Mulla Sadra's replies to the objection that if there were a change in substance, there would be no subject to undergo the change. These replies are based on the principle that existence has a fundamental priority with regard to quiddity, and the idea that in substantial motion the object that moves is identified with its motion. In short, the subject of substantial change is the changing substance extended through time.

\subsection{Comparative Studies of Substantial Motion}

3.21 Substantial Motion in Mulla Sadra Compared with Creative Evolution in Bergson (1996)

The author of this M.A. dissertation, Mehdi Ra'isi, finds a number of common themes in the works of Bergson and Mulla Sadra: the evolutionary progress of the material world, life (in Bergson) and existence (in Mulla Sadra) are in a constant state of flux, and are continuously being renewed, this progress is in the direction of perfection, both authors emphasize the continuous nature of time, and both hold that objects are extended through time. Both reacted against forms of atomism that were current in their respective intellectual environments, and both introduced 
the idea of continual change in opposition to those who took a more static view of truth. These philosophers differ in that Bergson emphasizes intuition, while Mulla Sadra takes a more rationalist approach.

\subsection{Substance in the View of the Empiricists and Islamic Philosophy} (1995)

In this M.A. dissertation, Ibrahim Abarsaji reviews the definitions of substance offered by Hobbes, Berkeley and Locke, and compares them with those offered by Fakhr Razi, Sohravardi and Mulla Sadra. He also compares the views of these philosophers on the existence of material and immaterial substances and on the status of the soul.

\subsection{Substantial Motion in the View of Mulla Sadra and Process} Philosophy (1994)

A number of Iranian and Western thinkers have seen a similarity between Whitehead's process philosophy and Mulla Sadra's views of substantial motion. Husayn Valeh attempts to sort through the similarities and differences between these traditions of thought on such topics as object/activity duality, the material and the immaterial, the unity of God and His relation to existence and the world, the universality of motion in the material world, continuity and unity, and the nature of time.

\subsection{Historical Studies of Substantial Motion}

3.31 The Roots of Substantial Motion in Mysticism, Philosophy, and Theology Prior to Mulla Sadra (1992)

Ahmad Abedi (now a member of the philosophy faculty at the University of Qom) wrote his M.A. thesis on the precursors to Mulla Sadra's doctrine of substantial motion. Prof. Abedi traces the idea of substantial motion to the idea of constant creation, repeatedly mentioned in the Qur'an, as developed in the writings of the Sufis. Among Muslim philosophers and theologians, the idea of substantial motion was not accepted by most writers, although there were a few who alluded to the idea, including the Ikhwan al-Safa, Hamid al-Din Kermani and Sohravardi. 


\section{Summary}

From this brief overview, one can get a rough picture of the sort of research that has been done over the last fifteen years in Qom about the divine essence and substantial motion. It is plain that Mulla Sadra's thought continues to dominate Islamic theology and philosophy as it is studied at the graduate level in Qom. On the other hand, the philosophical work done in this tradition is not merely apologetic in nature. Often details of Mulla Sadra's views are subject to criticism and emendations or improvements are suggested by those who teach Islamic philosophy. There is also a strong current of thought in Iran, the Maktab-e Tafkik (School of Separation), which is fundamentally opposed to basing a Shi'ite theology on a philosophical system such as Mulla Sadra's, although this sort of opposition is not reflected in any of the dissertations mentioned here. Likewise unrepresented here is the tendency found among some Iranian intellectuals today to reject the tradition of Islamic philosophy altogether. For example, some Iranian Marxists have suggested that the concept of substance should be completely abandoned, and the great Muslim philosopher, exegete and theologian, Allamah Tabataba'i roundly rejected such suggestions as absurd because of the independence criterion of substance: all existents exist dependently or independently; if there were no substances, everything would be an accident, and in that case the accidents would attain independent existence and so become substances.

We also find that while the discussions of these topics are mostly confined to the Islamic cultural orbit (which includes the work of Maimonides), an increasing amount of comparative work is being done, as reflected in our list in references to Bergson, process philosophy and empiricism. This trend is increasing, and I am sure that if another review of these topics is done after another fifteen years, the number of dissertations dedicated to comparative philosophy and theology will be found to have increased tremendously.

\section{REFERENCES}

Chittick, W. 1998 The Self-Disclosure of God, Albany: SUNY Press.

McDermott, M.J. 1978 The Theology of Al-Shaikh Al-Mufid, Beirut: Dar el-Machreq. Shaykh Mufid 1371 A.H. Awa'il, Tabriz: Charandabi.

Zayn al-'Abidin 1987 The Psalms of Islam: Al-Sahifat al-Kamilat al-Sajjadiyya, W. Chittick, tr., London: Muhammadi Trust. 


\title{
Ghazali on Immaterial Substances
}

\author{
BORIS HENNIG, SAARBRÜCKEN
}

\section{Preamble}

In this paper I will attempt to extract a positive doctrine on the substantiality of the human soul from Ghazali's critique of the Aristotelian philosophical tradition. Rather than reflecting on the possibilities and limitations of intercultural dialogue, my aim is to directly engage in such dialogue. Accordingly, I will not suppose that we need to develop and apply external standards according to which one of the two philosophical traditions addressed here, Western and Islamic, may turn out to be superior. Up to a certain point, Western and Islamic philosophy are virtually indistinguishable regarding their style, the main topics, and the arguments discussed, which both take over from Aristotle and the Neoplatonists. Further, at least up to Ghazali, no Islamic philosopher actually employs standards of rationality that would differ from the standards also accepted in the West. Ghazali himself would certainly be at least as disturbed by a valid philosophical objection to his claims as any other serious philosopher. He does not pursue another kind of project, but submits to the same standards of truth and validity, as far as philosophical argument reaches. His point is, of course, that these standards do not reach as far as some philosophers suppose. But this, again, is not a particularly "Islamic" insight.

So, although I will discuss Ghazali against the background of a roughly outlined Western discourse about the mind as a substance, stretching from Augustine to Locke, this is not meant to be a confrontation between different styles of thinking or points of view. Insofar as Ghazali defends and refutes philosophical arguments, his style and point of view are thoroughly universal, as much as the style and point of view of Augustine, Descartes, and Locke. He could have directly contributed to their very project, and the following can be read as an attempt to reconstruct what his contribution might have been. I will start with a rough and superficial sketch of the Western philosophical tradition in question. Then I will turn to Ghazali by first outlining the general framework within which his talk about substances must be understood. I will further discuss two of the arguments for the eternity of material and immaterial substances that he 
rejects. It will turn out that in order to understand how substances can come into being and cease to exist, we need to distinguish between two kinds of possibility, and accordingly between two ways in which possibilities may be said to inhere in an underlying substance. This will lead to an important and very general comment on immaterial substances: such substances are not related to forms and possibilities by possessing them as their own forms and potentials. It is precisely for this reason that it is misleading to think of the mind as an entity that has certain properties.

\section{Immaterial Substances}

In book VII of his Confessions, Augustine tells us that at some point in his life, he had an important insight when reading Neoplatonic philosophers. He does not name any specific Neoplatonic thinker or theorem, but his insight is clear and simple enough. He reports that he realized that there are entities that are not material: neither material substances nor properties of them, nor relations between such substances. Significantly, this insight helped him to solve the problem of evil, and the most important such thing he mentions is truth. In Augustine, the immaterial is the normative. Whereas there may perhaps be a way of identifying the established, finite set of all actually known facts with a set of relations between material objects, pieces of paper, human bodily organs, brains, their properties, and so on, there can be no such identification for truth. The truth always goes beyond the set of true assertions that we actually endorse. Since "truth" is also a name that Christian philosophers like Augustine habitually apply to God, Augustine does not hesitate to conclude that God is immaterial, and further, that the human soul, being made in his image, is an immaterial thing.

Descartes provides a rigorous argument in support of the Augustinian insight. He shows, in his first two Meditations, that our understanding of what it means to be a thinking subject need not involve any understanding of what it is to have a material body. Before we accept anything else as a fact, we already know that we think. Thinking, Descartes explains, is conscious activity. This however means that consciousness itself cannot be another kind of thinking. First, since all thinking is conscious activity, this would lead to a regress. Second, it does not seem true that we explicitly think of everything of which we are conscious. Anyway, Descartes nowhere claims that consciousness is anything like introspection, selfobservation, or reflective thought. Consciousness goes beyond our actual 
thinking in the same sense in which the truth goes beyond our actual asserting. This is so because similar to truth, consciousness is concerned with our thoughts and actions from a normative perspective. Consciousness is primarily concerned with the value of our own activity, and with our relation to this activity. Just as we need not state that what we say is true in a separate statement, we need not think that we think in a separate thought. Consciousness amounts to an implicit evaluation of a thought as our own. More specifically, it amounts to taking the stance that Descartes explicitly takes towards his own thoughts in his first two Meditations. He sets out to endorse only such thoughts that are most reliable that are immediately evident to his mind. He thus rejects all knowledge claims based on testimony, and all opinions that depend on possibly unreliable means, leaving only the thoughts that he can defend all by himself. The core subject of this and only this kind of activity is then called "res cogitans" thinking subject. To be conscious of a thought or action is accordingly to regard oneself as immediately and fully responsible for defending this thought or action.

That the conscious subject that Descartes isolates in the beginning of his Meditations is in its essence a locus for responsibility and liability for thoughts and actions explains, first, why Descartes can infer the existence of God from the existence of the conscious subject. To act responsibly is to suppose that there is a correct evaluation of one's acting as good or bad, right or wrong, that need not coincide with any actual evaluation, not even one's own. The notion of a responsible agent therefore implies the notion of an ideal evaluation. From this Descartes infers the existence of God, an ideal evaluator. Again, the truth transcends the merely factual.

Second and more importantly, that the res cogitans is in its essence a responsible subject of thought and action justifies the title of a thinking substance; at least to a certain extent. The important point to note here is that an agent can only be liable and accountable for thoughts and actions insofar as she persists over time and is clearly distinct from other instances of her kind. In this sense, the subject of conscious activity can only be a persisting individual. Since the terms in which we trace such subjects over time are not the same as the means by which we identify material bodies or parcels of matter, it is further legitimate to speak of immaterial substances. The point is not that they are entirely unrelated to matter, but that there is something about them that cannot be captured by a purely materialistic description. In order to say what it means to be responsible for an action or a thought, we need to transcend the material and the factual, since to be 
responsible is not the same as to be actually held responsible. This insight is again emphasized by Locke: persons are identified and individuated not merely in terms of their bodily features, but in terms of their life histories; more precisely, in terms of the actions and thoughts for which they are accountable. And Locke also makes clear that it does not matter whether persons are actually held responsible for what they do by other humans, or consider themselves responsible for what they did. What matters is the evaluation by God, the ideal evaluator, in the final judgment (Essay II,xxvii,26).

This is, then, the motivation for calling the mind an immaterial substance - and for Cartesian Dualism in general. Humans subject their conscious thoughts and actions to an evaluation according to standards such as truth, correctness, goodness. But no finite, actual set of evaluations and meta-evaluations guarantees the satisfactions of such standards. What humans say may be false and what they do may be wrong even if no human on earth ever notices. In this sense, the standards themselves are immaterial. Insofar as we act and think, we are subject to a standard that transcends the material world, and we bear our responsibility regardless of what happens to our material bodies. ${ }^{1}$ Let me now turn to the ontological framework within which immaterial substances are traditionally located.

\section{Aristotelian Top-Level Ontology}

According to a metaphysical framework that Ghazali largely accepts, there are two kinds of entities: those that are in something else, such as accidents and forms, and those that are not in anything else $(3,41,66){ }^{2}$ Entities that do not exist in any receptacle (mahal) or substratum (maudu') are called substances (jawhar, 5,24,90). There are three kinds of substances. Some substances are receptacles for accidents and forms; others are selfsubsistent $(3,41,66)$. The self-subsistent substances divide into two kinds. Some of them are attached to substances that are receptacles; others are not essentially related to any other thing at all.

Instances of the first kind of substance, which are receptacles for

\footnotetext{
${ }^{1}$ This paragraph is a rough summary of results I develop more thoroughly in Hennig 2006.

2 All references are to Ghazaliii 2000, ed. Marmura. The numbers refer to the discussion, paragraph and page respectively, such that the above " $3,41,66$ " refers to the Third Discussion (which is found in part I), §41, p. 66. I have occasionally modified the translation.
} 
accidents and forms, are mere extension (madda) and bodies (jism). According to a view that Ghazali attributes to Avicenna, the human soul is a substance of the second kind: it is not itself a receptacle but individuated only by being attached to a body that is a receptacle of forms and accidents $(19,9,202-3)$. The third kind of substance is exemplified by the divine intelligences, which are immaterial, unique in their kind, and not attached to any particular, material body.

\section{The Extended Substance}

Ghazali further endorses an Aristotelian principle according to which every change requires an underlying subject that remains, in some respect, the same $(17,36,176)$. The "philosophers" (Farabi and Avicenna) argue that when a thing comes into being, it changes from non-existence to existence, and hence there must be a substratum that remains the same during the change from non-existence to existence. Before a thing comes into existence, it must have been possible for it to exist, and this possibility must have been present in a receptacle (mahal). Therefore it seems that if something $\mathrm{A}$ is possibly coming to be, something that is already actual must have the potential for becoming A. Hence, the universe in its entirety can have no beginning, since there would have to be a receptacle for its possibility of coming to be. This receptacle, however, will already have to be an extended thing (madda, 1,113,41).

In general, since a substance does not inhere in anything, there can be no substratum underlying the process by which a substance comes to be. It is easy to see how a property comes to be exemplified: something that may possibly have this property turns into something that actually has it. No such account, however, can be given for the way in which substances come into being. This appears to entail a Spinozistic ontology, according to which there is only one eternal substance, and everything that is subject to change inheres in this substance. Hence, the argument of the philosophers, as Ghazali states it, leads to undesirable conclusions.

\section{The Thinking Substance}

Ghazali picks up the same issue again in his discussion of the persistence of the soul (nafs). He begins by stating the following philosophical argument to the effect that the soul cannot cease to exist. A thing may cease to be for three reasons: by lack of support by an underlying 
substratum, by encountering its opposite, or by something else's execution of a power. But the soul does not cease to exist in the first way, since it needs no support from an underlying substratum. Rather than being imprinted in the body as its receptacle, the philosophers argue, the soul uses the body as a tool, and the destruction of a tool does not entail the destruction of its user. Second, there are no negative substances, such that a substance could be destroyed by encountering its negative counterpart. Third, the non-existence of a substance is not a positive fact and can therefore not be specified as a condition of success for the execution of a power. Since a power must be defined in terms of its successful execution, this means that there can be no power for destroying a substance $(19,2-$ 5,201-2).

These arguments are of doubtful validity. In order to establish the first, the philosophers would have to show that the soul does not in any sense depend on the body for its existence. But even if the soul is not imprinted in matter as its receptacle, it may still cease to exist in the absence of the body to which it is attached, just as humans will cease to exist in the absence of air without being imprinted in it. The specific way in which the soul depends on its body may be that it has its identity only insofar as it is attached to this body rather to another (19,8-15,202-4). And as Ghazali argues elsewhere, we do in fact never refer to ourselves without in some way or other referring to our body $(18,53,192-93)$. Therefore, it might well be that the soul depends on the body even if it uses it only as a tool. At any rate, Ghazali concludes, it is not logically impossible that God should be able to destroy the soul, and no one guarantees that the list of possible ways of ceasing to be that the philosophers offer is exhaustive $(19,16$ 17,204-5).

In a second round, Ghazali has the philosophers elaborate on their first argument. Since a substance does not exist in a receptacle, they argue, it cannot cease to exist. For ceasing to exist is a change, and hence, there must be an underlying substratum that undergoes this change. This substratum, however, would have to underlie all stages of the change in question, such that first, the substance would be supported by this underlying substratum as long as it exists. But a substance needs no such support. Second, if the substratum underlies all the stages of the soul's ceasing to be, it would still have to be there in the absence of the soul-but there is nothing that belongs to a human being that would still be present when the soul has perished. This leads us back to the argument for the eternity of the extended substance. The substratum that remains when the 
soul has ceased to be would have to be a receptacle for a potential of a soul to be, in the same way in which extension (madda) is the receptacle for a potential of a body (jism) to be. This however would turn the soul into a kind of form or accident, which would need something like extension as its receptacle $(19,18-22,205-7)$.

\section{Ghazali's Way Out}

The main argument for the eternity of both extended and thinking substances is thus that the potential for a substance to exist would have to inhere in something else as long as this substance does not exist. But then, there would also be a receptacle on which the substance would depend for its existence when it exists.

Against this, Ghazali argues that possibilities do not require a real substratum and that we rather "call that possible which the intellect ( $\left.{ }^{c} a q l\right)$ may suppose to be there without encountering a contradiction" $(1,116,42)$. That is, the possibility that a substance exists is not a possibility for it to exist. There need only be an intellect that grasps this possibility and that is able to realize it. But this intellect is not the thing for which it is possible to exist. The intellect already exists, and the thing that possibly exists does not. Ghazali claims that this may be seen by considering the following arguments.

First, there would have to be a substratum not only for the possibility of things to come into existence, but also for their refusal to do so $(1,117,42){ }^{3}$ Although it might seem that a refusal to be must still be the refusal of some existing thing to be, this is not the case. There "are" things that may never actually be the case. Such things need no receptacle in order not to be, and hence their refusal to exist does not need any receptacle $(1,122,43$; $1,129,45)$.

Second, Ghazali argues, that which comes into being when an accident comes to be in a receptacle is not an abstract and universal form (kulliya mujarrada, 18,9,181), but only one of its particular instances. The universal itself does not come to be, but still, there is a sense in which a non-instantiated universal is only possible and not actual. That the universal is possible in the sense of being possibly instantiated does not

\footnotetext{
3 Marmura translates imtina" as "impossibility", such that the claim would be that there must be a substrate for the impossible. This does not follow and "refusal" is a more natural translation; at any rate imtina' is not literally the opposite of possibility (imkān).
} 
mean that it may itself come to be; it rather means that something else may come to be: one of its instances. By the same token, the soul may be said to be possible not because there actually is a receptacle in which it may come to be, but rather because something else may come to be: a bodily thing to which the soul may come to be attached $(1,118,42)$.

Hence, although a universal form may only be actual by being realized in a particular instance, this does not mean that it needs this instance as a receptacle for its existence. The form does not come to be by being instantiated; it only comes to be instantiated. Likewise, the soul may be merely possible as opposed to actual as long as it is not attached to a body. But that does not mean that it comes to be in a body that would be its receptacle. It only means that it comes to be attached to a body.

\section{Forms vs. Intentions: Sura vs. Ma nan}

The comparison between universals, souls, and possibilities is the most important step in the line that Ghazali takes against the philosophers. Both forms and possibilities may exist without inhering in a receptacle. They may be said to inhere in the intellect ( $a q l$ ), but then the intellect will not be their receptacle-that they inhere in the intellect does not mean that the intellect exemplifies them.

We have already seen that the "philosophers" distinguish between two kinds of substance: substances that are receptacles of forms and accidents, and others that are self-subsistent. According to an account that a writer like Avicenna might put forward and with which Ghazali agrees, there are also two kinds of accidents or forms. There are, corresponding to the first kind of substance, forms and accidents that only exist in a receptacle (sura = Greek morphe). These are always forms of some particular thing: particular form-instances that come into existence when a thing actually has a property. Second, corresponding to the second and third kind of substance, there are forms that do not require a bodily receptacle in order to exist ( ma nan $=$ Greek ennoia, translated into Latin as intentio). These are the universals that may be present in the mind without necessarily being instantiated by anything $(18,3,179)$. In his 18th Discussion on the immateriality of the soul, Ghazali makes extensive use of the distinction between sura and ma nan. Although universals are indivisible, he argues, they may still exist in a divisible substratum such as the brain, since they need not be instantiated by this substratum. The soul can accordingly be in a body without being its form; that is, it may depend on the body for its 
existence without being imprinted in it.

\section{Potentials Require a Receptacle, Possibilities Require a Substratum}

Although Ghazali himself presents his argument against the eternity of extended and thinking substance only in order to "throw dust in the face" of the alleged proofs $(1,134,46)$, we may extract from his criticism two distinctions that are still of crucial importance.

First, it has emerged that one should distinguish between the substratum $\left(m a w d u^{\prime}\right)$ of a universal or possibility and its receptacle (mahal). The receptacle of a possibility or universal is that in which it is present when it is actual. The receptacle of a color must be an extended thing. The substratum of a universal or possibility is that in which it may exist without necessarily being actual. The substratum of a color need not be an extended thing. According to Ghazali, the intellect may function as a substratum for universals and possibilities.

The receptacle of a possibility can only be an existing thing that may eventually actualize this possibility. For instance, it is possible that my son catches a cold since I have a son who does that quite often. In this case, my son is the receptacle of a potential for getting a cold. But this is not the only way in which possibilities may be there. For in a different sense, it is possible that my daughter catches a cold, although I do not yet have a daughter and may never have one: it is possible that I may have a daughter who has a cold. These two senses in which a state of affairs is possible have also been distinguished in terms of de re and de dicto modality: one may say that it is (de re) possible for my son to catch a cold, but not literally that it is possible for my daughter, since there is no daughter of mine for it to be possible for.

The second distinction that we may extract from Ghazali's discussion of the philosopher's "substance" is closely connected to this distinction between de re and de dicto modality. We may distinguish between possibilities that require a receptacle in order to become real and possibilities that do not require such a receptacle, but may exist in a substratum such as the intellect. The former may be called potentials of the receptacle in question. This distinction mirrors the division of forms into universals (ma nan) and particular form-instances (sura). Potentials are particular possibility-instances, as it were, and they require a receptacle in order to exist. De dicto possibilities do not require a receptacle, but only a substratum such as an intellect in order to exist. 


\section{Substance Ontology Revised}

Traditionally, a substance is said to be something that does not inhere in anything else, but in which other things such as forms and accidents inhere. This is, admittedly, a vague formulation, and much more would have to be said about what "inherence" means in this context. The question that Ghazali raises is whether a substance is supposed not to inhere in another thing (1) as its receptacle or (2) as its substratum. If a substance may not inhere in any substratum whatsoever, it will be difficult to explain how substances come and cease to be. On the other hand, if the relevant kind of inherence were restricted to inherence in a receptacle, it would seem that space and matter are the paradigm - if not the only — cases of substance.

If we admit that forms may also inhere in substrata without being forms of these substrata, we can explain how it can be possible that the universe exists before there is anything other than the divine mind. Hence, the best thing to do is to account for both kinds of inherence. It will then turn out that the mind or intellect is not a substance in the same sense in which a body is a substance, and that thoughts inhere in the mind not in the sense in which properties inhere in bodies. The mind is not a receptacle, but a substratum of thought and action, whereas bodies are only receptacles of their properties. Likewise, bodily substances can only host potentials, and de dicto possibilities can only inhere in the mind.

What matters here are not so much the possibly existing substances, but rather the further substances in which their possibilities subsist before they exist. These are the immaterial substances, mind and intellect, and according to Ghazali, they are related to that which subsists in them in a peculiar way. The distinction of substances and inherence relations into two types is not yet fully reflected in the top-level ontology presented earlier on in this paper. In addition to receptacles and things that inhere in them, we need to introduce entities that subsist in immaterial substances without inhering in them. This new class will include universals, de dicto possibilities, and probably also intentions and thoughts. All these "mental entities" do not inhere in the mind in the sense that they are forms of the mind or possibilities for the mind. Not even thoughts are forms of the mind, since we do not literally look inside our own minds when we contemplate them. Thoughts are possible facts. Likewise, intentions are not in the mind as in a receptacle, but are rather certain possibilities to act. These consequences are not elaborated by Ghazali, but they appear natural 
and they are of utmost importance. The revision of the Aristotelian toplevel ontology that Ghazali recommends leads to an insight into the nature of the mind. Although there are good reasons for calling the mind a "substance", since it is an individual and persistent locus of responsibility, there are also good reasons not to apply the schema of form and matter to this substance. Immaterial substances thus differ radically from material substances.

Ghazali thus offers an alternative ontological framework for drawing the distinction between material and immaterial substances with which Augustine, Descartes and Locke were concerned. I have argued that the mind is a subject of thoughts and actions in that it is responsible for them rather than exemplifying them as its properties. The way in which this relation of the mind to its activities differs from spatial relations or the relation between an extended thing and its properties motivates the Cartesian distinction between extended and thinking substances and explains why the soul is thought to be an immaterial substance. In Ghazali's terminology, the thinking substance differs in that it is not a receptacle of its thoughts and actions, but a substratum. He draws the same distinction, but not in terms of materiality.

\section{REFERENCES}

Ghazali 2000 The Incoherence of the Philosophers, ed. M. E. Marmura, Provo, Utah: Brigham Young University Press.

Hennig, B. 2006 Conscientia bei Descartes, Freiburg: Alber Verlag. 
